\title{
An empirical evaluation of the use of video films in training: A behaviouristic analysis
}

\author{
C. Viedge* and P.A. Taffinder \\ Division of Management Studies, National Institute for Personnel Research, P.O. Box 32410, Braamfontein, \\ 2017 Republic of South Africa
}

Accepted 2 March 1987

\begin{abstract}
Considerable organizational resources are expended annually on training, yet little empirical research is undertaken to investigate the problem of transfer of training to the workplace. Video films are an integral part of many training courses and it is critical to evaluate the efficacy of such films in developing the intended skills. Within the operant behaviouristic perspective, an $\mathrm{ABAB}$ reversal experiment was conducted during four business game periods of a training course. The experimental objective was to assess the impact of the principles presented in a training film on the decision-making behaviour of six managers from an engineering research/ production facility. A cue-board summarizing the decision-making principles presented in the film was unobtrusively introduced during the two ' $B$ ' phases of the experiment. Frequencies of the target behaviour were recorded by two independent raters across all consecutive ' $A$ ' and ' $B$ 'experimental phases. No functional relationship was found between the use of the decision-making principles and the introduction of the cue-board. In other words, despite the use of a cue-board to prompt decision-making behaviour, no transfer of training from the video-film to the analogue working environment of the business game was observed. Some implications of these results for employing video films in training are discussed.
\end{abstract}

\begin{abstract}
Alhoewel daar jaarliks 'n aansienlike hoeveelheid organisasiebronne aan opleiding spandeer word, word daar min empiriese navorsing onderneem om die probleem van oordrag van opleiding na die werkplek te ondersoek. Videofilms vorm 'n integrale deel van vele opleidingskursusse en die evaluering van die gebruikswaarde van sodanige films in die ontwikkeling van die beoogde vaardighede is van kritiese belang. ' $n$ ABABomkeringseksperiment is, binne die operante behaviouristiese perspektief, tydens vier besigheidspelperiodes van 'n opleidingskursus uitgevoer. Die eksperimentele doelwit was die bepaling van die impak van die beginsels, wat in ' $n$ opleidingsfilm aangebied is, op die besluitnemingsgedrag van die ses bestuurders van ' $n$ ingenieurs-navorsings/produksie-fasiliteit. 'n Sleutelbord, wat die besluitnemingsbeginsels wat in die film aangebied is bevat, is onopsigtelik bekendgestel tydens die twee ' $B$ '-fases van die eksperiment. Twee onafhanklike waarnemers is gebruik om die frekwensie van die teikengedrag op te neem regdeur al die opeenvolgende ' $A$ '-en ' $B$ '-eksperimentele fases. Daar is geen funksionele verband gevind tussen die gebruik van die besluitnemingsbeginsels en die bekenstelling van die sleutelbord nie. Met ander woorde, geen oordraging van opleiding vanaf die videofilm na die analoë werksomgewing van die besigheidspel is waargeneem nie, ongeag die gebruik van 'n sleutelbord om besluitnemingsgedrag aan te spoor. Sommige van die implikasies voortspruitend uit hierdie resultate vir die aanwending van videofilms tydens opleiding, word bespreek.
\end{abstract}

*To whom correspondence should be addressed

\section{Introduction}

Considerable organizational resources are committed each year to management training and development, yet little attention is paid to the transfer of such training from the development programme to the workplace (Marx, 1982). There is, moreover, a pressing need for empirical investigations that examine the usefulness of training techniques (Goldstein, 1980). A prerequisite in training is the requirement that mastery of the principles presented to trainees must be ensured, before the transfer of such training can be investigated. It follows that if mastery is attained, generalization of the newly learned behaviour to the work environment should be substantially enhanced. Wexley \& Latham (1981) refer to this process as positive transfer and define it as the extent to which individuals use on the job what they have learned in the training situation.

The experiment reported here investigates one aspect of positive transfer of training. Its aim was to assess whether concepts presented in a training video film would be applied in a business game which formed part of the overall management training programme.
Central to the concept of transfer of training is the learning process. However, in general there is a paucity of research into the learning process involved when training videos are used.

Training literature has focused on the technicalities of training videos (Berry, 1981; Crowther, 1974; Esterhuizen, 1983), or alternatively comparing the effects of video as against film presentation (Davis, Hodder, Junus, MacBain, MacCormick, MacDonald, Simms, \& Whiston, 1983). The dearth of scientific data on the process of positive transfer has occasioned widespread concern about the wisdom of investing blindly in training. Indeed, Georgenson (1982) has estimated that only $10 \%$ of the money spent on training in the U.S., results in actual behavioural change back on the trainees' jobs. The need to examine positive transfer is all the more urgent if we are cognizant of the millions of Rands invested in training annually.

\section{Theoretical basis of the experiment}

The operant conditioning perspective of Skinner (1953, 1974) describes several principles which explain the 
behaviour of human organisms in terms of environmental antecedent conditions, the behaviour itself, and the consequences of such behaviour. This functional analysis is referred to as the three-term contingency (Skinner, 1974):ANTECEDENT; BEHAVIOUR; CONSEQUENCE.

Behaviour, in this analysis, is a function of antecedent events and consequences of the behaviour. An antecedent stimulus sets the occasion for behaviour to occur. Behaviour that has reinforcing consequences will show an increase in the probability of recurrence; behaviour that has no consequence or a punishing consequence will tend to decrease in probability of recurrence. The threeterm contingency of antecedents, behaviour, and consequences provides a delineation of how behaviour is evoked and what maintains or reinforces it. The application of operant principles to business and organizational settings is a comparatively new field and is termed Organizational Behaviour Management (OBM). Frederiksen \& Lovett (1980: 196) characterize OBM as 'the application of principles of behavioral psychology and the methodologies of behavior modification/applied behavior analysis to the study and control of individual or group behavior within organizational settings'. Finally, the distinguishing feature of OBM is the experimental method employed, utilizing response specification, ongoing behaviour assessment, and within-group performance comparison (Taffinder \& Viedge, 1986).

\section{Method}

The concept of positive transfer implies that the criterion against which training should be judged is that it brings about a change in behaviour on the job. However, it is possible to test whether mastery of the applicable skills has been immediately achieved in training, by observing the frequency at which such behaviour is exhibited under conditions analogous to the work situation. A business game provides a structured environment within which simulated work conditions can be created and the behaviour of participants assessed.

\section{Subjects and setting}

The experiment was conducted during a four-day management training course. The subjects comprised the six delegates who participated in the course. Five were engineers and one was an accountant, all holding management positions in a research/production facility specializing in the manufacture of electrical components. All the subjects were male with an age range of $35-55$ years, a mean age of 45 years, and a standard deviation of 4,62 years.

The objective of the management training course was to promote managerial effectiveness through team development. To this end, a business game was monitored and video-recorded using closed circuit television (CCTV). The video recordings served as a means of providing feedback to the group on their managerial interactions and business game performance. The course structure was such that the training material presented was intended to be incorporated by the delegates in the analogue environment of the business game. The course delegates participated in ten 30 -minute periods of the business game. These were spread across the four days of the course. An integral part of the business game was the submission by the trainers of written communications to the participants during the running of the game.

\section{Dependent variable}

The dependent variable isolated in the experiment was decision-making behaviour. The training input relating to decison making was the video film 'DecisionDecisions' (Video Arts, 1978). The film specified five guidelines for decision making. These were:

1. Define the decision.

2. Collect the facts.

3. Consult amongst the group.

4. Take the decision promptly.

5. Communicate the decision in writing.

In behaviour analytic terms the five guidelines for decision making were operationalized as follows:

1. Defining the decision. Verbalization of the perceived problem. Verbalization of the parameters of the problem. Prompting or entreating others to define the decision, followed by an appropriate response.

2. Collect the facts. Verbally gathering or stating information relating to the decision. Prompting or entreating others to collect the facts, followed by an appropriate response.

3. Consulting amongst the group. Eliciting facts and/or opinions from particular group members. Substantiating the facts or gaining consensus amongst the group. Prompting or entreating others to consult amongst the group, followed by an appropriate response.

4. Take the decision promptly. Verbalization of the decision taken before the end of the business game period. Prompting or entreating others to take the decision promptly, followed by an appropriate response.

5. Communicate the decision in writing. Provision of a written statement of the decision taken. Prompting or entreating others to communicate the decision in writing, followed by an appropriate response.

\section{Apparatus}

To act as a potential antecedent stimulus (i.e. to set the occasion for systematic decision making as portrayed in

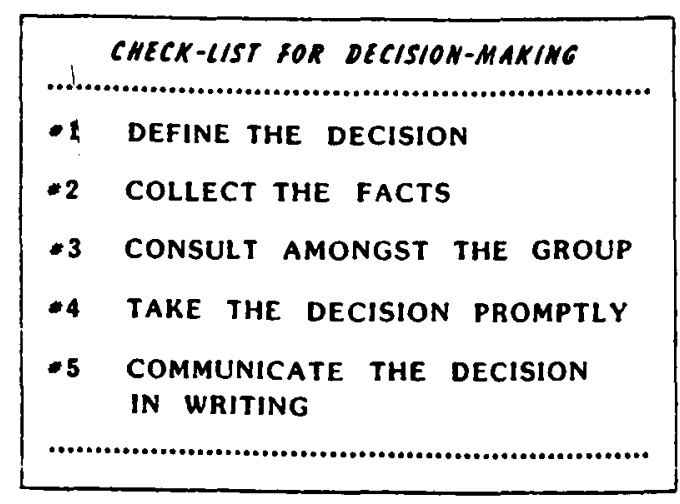

Figure 1 Facsimile of the decision-making cue-board 
the video film), a cue-board $(42 \mathrm{~cm} \times 28 \mathrm{~cm})$ was devised to display a check-list of the five guidelines (see Figure 1).

In addition, CCTV video recordings were made of the business game periods for later observational assessment by two independent raters. This was accomplished by means of a behavioural rating scale for assessing the frequency of the five decision-making behaviours for each of the six subjects.

\section{Statement of hypothesis}

A key assumption of this experiment was that the mere exposure of subjects to a training video film would not, on its own, modify their behaviour either in the business game or in the work environment. However, a cueboard would serve as a systematic guide for application of the decision-making principles when required in the business game.

Thus, the following experimental hypothesis was framed: The presentation to the subjects of a cue-board (antecedent stimulus) will result in a frequency increase in the dependent variable (i.e., decision-making behaviours).

It was presumed, in terms of this hypothesis, that the cue-board would function as an antecedent stimulus to set the occasion amongst subjects for exhibiting the decision-making behaviours depicted in the video film. In this sense, the cue-board was designed to facilitate positive transfer.

\section{Procedure}

$\mathrm{An} \mathrm{ABAB}$ within-subjects reversal design (Dickinson \& O'Brien, 1982) was used in this experiment. The reversal design is an extension of the comparison method. Data collected during the baseline phase (referred to as A1) prior to the introduction of the independent variable, are compared to the data collected during the intervention phase (referred to as B1). Thereafter, the conditions are reversed (i.e., the independent variable is withdrawn) and data are collected (referred to as A2): if behaviour changes during the intervention then returns to baseline level during the reversal condition, one can reasonably assume that the intervention was responsible for the behaviour change. Increased credibility is added if the intervention is reintroduced (referred to as B2) and the behaviour changes as in the first intervention phase. The $\mathrm{ABAB}$ within-subjects reversal design is particularly well-suited to small samples as the subjects serve as their own controls in the experiment (Komaki, 1982).

Using the business game, it was possible to implement the reversal design in the last four periods with no disruption to the normal training programme. The video film 'Decisions-Decisions' was shown to the subjects before the baseline phase (A1). The video film was supported by means of a lecture and discussion led by the trainers. The sequence of the experiment was as follows: Video film shown.

BASELINE A1 No cue-board present. Behaviour assessed on rating scale.
INTERVENTION B1 Cue-board introduced. Behaviour assessed on rating scale.

REVERSAL A2 No cue-board present. Behaviour assessed on rating scale.

INTERVENTION B2 Cue-board reintroduced. Behaviour assessed on rating scale.

The intervals between the game periods allowed the experimenters to introduce and remove the cue-board unobtrusively.

In order to specifically generate decision-making behaviour, a typed communication in the form of a simulated telex marked urgent was given to the subjects at the beginning of each of the four experimental periods. As far as possible, the contents of the four 'telexes' were similar, to control for possible variations in their potential for eliciting decision-making behaviour.

The frequency of decision-making behaviours (as per the operational definitions) was determined by a tally of each observed occurrence for each subject, using the rating scale. Only decision making related to the simulated telexes was rated. The rating was performed subsequent to the experiment by assessing the video recording of the game periods. The experimenters independently rated the target behaviours. Final consensus ratings were arrived at by discussion or by re-assessing the video recordings.

\section{Results and Discussion}

The data failed to support the experimental hypothesis. Table 1 displays the frequency of decision-making behaviours in each of the four experimental phases.

The data subtotals from Table 1 are reproduced in graphic form in Figure 2. The subtotals were employed to indicate the global incidence of decision making in response to the four 'telexes'.

As can be seen from the trend in the graph, no functional relationship exists between the independent variable (i.e., the cue-board) and the dependent variable (i.e., decision-making behaviour).

Furthermore, the experimenters' qualitative assessment of the subjects' decision-making behaviour tended to support the frequency ratings. There was no indication that decision making was more systematic or effective with the cue-board present $(B 1 ; B 2)$ than with it absent $(\mathrm{A} 1 ; \mathrm{A} 2)$. A notable feature of the data was the marked decline from the baseline level to the final phase level.

Table 1 Tabulated frequencies of decision-making behaviours in each of four experimental phases $(N=6)$

\begin{tabular}{lrrrr}
\hline & $\mathbf{A}_{1}$ & $\mathbf{B}_{1}$ & $\mathbf{A}_{2}$ & $\mathbf{B}_{2}$ \\
\hline Define the decision & 9 & 8 & 1 & 3 \\
Collect the facts & 24 & 14 & 1 & 1 \\
Consult amongst the group & 14 & 4 & 1 & 4 \\
Take the decision promptly & 1 & 4 & 1 & 1 \\
Communicate the decision in writing & 1 & 2 & 1 & 1 \\
Subtotals & 49 & 32 & 5 & 10 \\
\hline
\end{tabular}




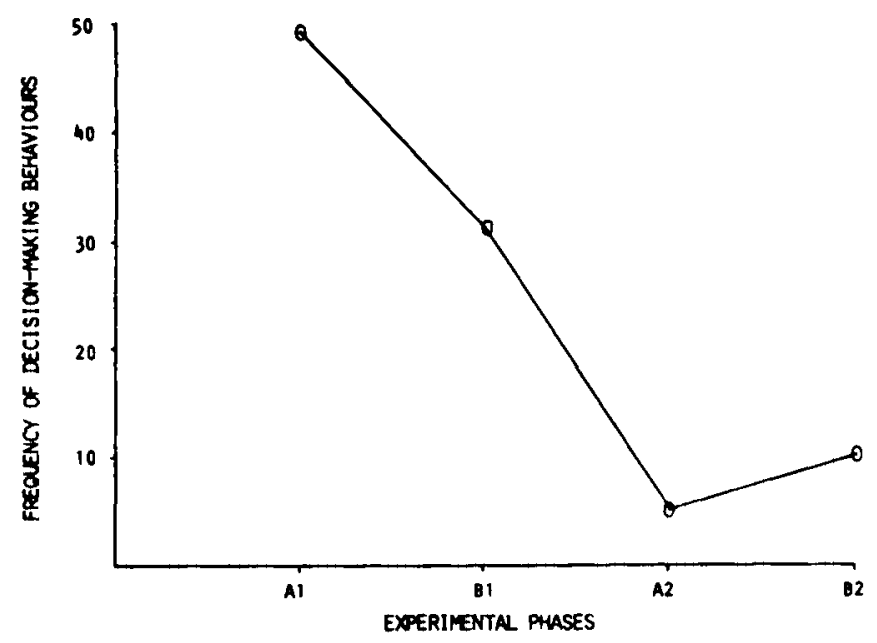

(SUCCEEDING BUSINESS gANE PERIODS)

Figure 2 Frequency of decision-making behaviours across four experimental phases $(N=6)$.

The absence of any functional relationship between the independent variable and the dependent variable indicates that the cue-board failed to act as an antecedent for decision-making behaviour. That is, there was no positive transfer from the training situation (i.e., presentation of video film) to the analogue environment (i.e., business game), even in the presence of an identical stimulus (i.e., the cue-board).

In keeping with operant theory, an antecedent is established when a neutral stimulus is present prior to or during the reinforcement of a particular behaviour. The experimenters expected that the film would demonstrate the reinforcing effects of making decisions in the manner portrayed. Therefore, by setting up the cue-board as an antecedent for effective decision making (as presented in the film), it was anticipated that the subjects would react to the antecedent with the appropriate decision-making behaviour. In order not to confound the effect of the cue-board, the experimenters deliberately refrained from actively reinforcing subjects for decision-making behaviour. This was done to provide a test of the capacity of the cue-board (as a summary of the film's principles) to initiate the target behaviour. In short, the cueboard should have functioned as a prompt for applying the film's decision-making principles in the business game. This it failed to do.

A possible explanation for this failure is the lack of reinforcing consequences contingent upon systematic use of the decision-making principles. In contrast, there were differential consequences for various other behaviours (competing with decision-making behaviour) during the business game periods, such that the activities of planning and completing the necessary financial game-forms were more likely to result in positive consequences. For example, the delegates' documentation for the game would be finished within the prescribed time. In point of fact, this highlights a problem in achieving positive transfer to the workplace. It is probable that the trainee, on return to work, will be reinforced for performing those tasks necessary to complete the work rather than for implementing newly learned strategies.

\section{Implications and Conclusions}

The current experiment investigated one aspect of the process of positive transfer when using video films in training. It was hypothesized that a training video with a summary cue-board would produce behaviour change in an environment analogous to the workplace. In the positive transfer process, it is critical to demonstrate mastery of new skills at this point, before the training can be expected to be transferred to the real work situation. Operant theory was used because of its focus on observable behaviour, which is congruent with the objective of training - i.e, to bring about an observable change in the trainees' behaviour.

While one should remain circumspect in generalizing from a single experiment, the negative results attained here have implications for business practice. The undoubted appeal of training videos, both to trainees in breaking the monotony of courses, and to trainers in reducing the time required in preparing such courses, must not blind management to the limited value of using films, on their own, as part of any serious training effort (Taffinder \& Viedge, in press).

For training films to be effective, trainers must contrive positive consequences to reinforce delegates for applying the film's principles, at least in an experiential session (to ensure mastery), and preferably also for applying the principles in the workplace. To merely show a video film and have a discussion on the principles and concepts covered, would seem to be a nonproductive, passive exercise. What delegates need is to experience the positive consequences of applying the principles demonstrated. Whether modelling, role-play, or experiential learning is used, is less important than a deliberate engineering by the trainer of a situation that will lead to a positive pay-off for the delegates' use of the training inputs.

From a practical viewpoint, the results of this study indicate, in a similar vein to Wexley \& Baldwin (1986), that trainers concerned with ensuring positive transfer should consider supplementing their training pro grammes with deliberate transfer strategies. In terms of operant theory, these strategies should focus on the provision of positively reinforcing consequences contingent upon delegates' appropriate application of training film inputs.

\section{References}

Berry, P. 1981. Seeing is believing: Using television in training. People and Profits, vol. 9, 21-24.

Crowther, B. 1974. Using films in training. In: An Introductory Course in Teaching and Training Methods for Management Development. Geneva: International Labour Office.

Davis, B., Hodder, R., Junus, K., MacBain, N., MacCormick, J., MacDonald, M., Simms, M. \& Whiston, D. 1983. The comparison of the effects of film and video-tape presentation on student recall. Prog. Learn. Educ. Techn., vol. 20, 115-116. 
Dickinson, A.M. \& O'Brien, R.M. 1982. Performance measurement and evaluation. In: Industrial Behavior Modification: A Management Handbook. O'Brien, R.M., Dickinson, A.M. \& Rosow, M.P. (Eds.). New York: Pergamon.

Esterhuizen, W. 1983. Tailor-made video programmes. IPM Manpower J., vol. 1, 30-31.

Frederiksen, L.W. \& Lovett, S.B. 1980. Inside organizational behavior management: Perspectives on an emerging field. J. Organ. Behav. Manage., vol. 2, 193-203.

Georgenson, D.L. 1982. The problem of transfer calls for partnership. Training Develop. J., vol. 36, 75-78.

Goldstein, I.L. 1980. Training in work organizations. Ann. Rev. Psychol., vol. 31, 229-272.

Komaki, J.L. 1982. The case for the single case: Making judicious decisions about alternatives. In: Handbook of Organizational Behavior Management. Frederiksen, L.W. (Ed.). New York: Wiley.
Marx, R.E. 1982. Relapse prevention for managerial training: A model for maintenance of behavior change. Acad. Manage. Rev., vol. 7, 433-441.

Skinner, B.F. 1953. Science and Human Behavior. New York: Macmillan.

Skinner, B.F. 1974. About Behaviorism. New York: Vintage Books.

Taffinder, P.A., \& Viedge, C. 1986. Organizational behaviour management: $A$ functional analysis of productivity. J. Industr. Psychol., vol. 12, 22-25.

Taffinder, P.A. \& Viedge, C. 1987. Training: Can videos do the job for you? Human Res. Manage., in press.

Video Arts, 1978. Decision-Decisions! London: Video Arts.

Wexley, K.N. \& Baldwin, T.T. 1986. Posttraining strategies for facilitating positive transfer: An empirical exploration. Acad. Manage. J., vol. 29, 503-520.

Wexley, K.N. \& Latham, G.P. 1981. Developing and Training Human Resources in Organizations. Glenview, Ill.: Scott-Foresman \& Co. 